\title{
Status and process analysis of koche, a traditional pastoral meat product in Kenya
}

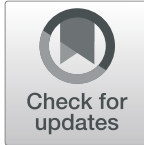

Grace Werikhe $^{1^{*}}$, Catherine N. Kunyanga ${ }^{1 \dagger}$, Michael W. Okoth ${ }^{1 \dagger}$ and Hassan G. Roba ${ }^{2+}$

\begin{abstract}
Meat is an important dietary component of the pastoral communities living in marginalized regions of Kenya. Indigenous meat processing, in particular koche processing, plays a significant role in the economic and social life of the Borana community. It contributes to animal-source protein as well as income generation as a livelihood activity by the Borana community. However, traditional processors face a number of challenges hindering further conventional development. The study was designed to assess the status and process analysis of koche, costs and returns of koche production and constraints limiting koche processors. A cross-sectional survey was therefore carried out in Isiolo and Marsabit towns to assess and analyse processing of koche product. Purposive sampling of all koche processors was used to identify study cohorts. Qualitative data were collected using key informant interviews and focus group discussions. Results revealed that all processors were women who largely relied on traditional techniques, often with low competitiveness and poor efficiency. The major constraints facing processors were lack of equipment to ease processing (100\%), lack of credit facilities (100\%), insufficient capital (90\%) and high costs of inputs (90\%). The return to labour and variable costs were Kshs 12.1 (0.121 USD) and Kshs 0.92 (0.0092 USD), respectively, while the marketing margin was estimated as $20.8 \%$. Based on the findings on the gross margin and analysis of returns, processing of koche product is a profitable business, thus a good investment opportunity. However, there is a need to overcome the challenges to enable the expansion of koche processing for better commercialization. Besides, addressing the challenges will help reduce post-production losses and remove market barriers of the koche product. This will expand the market access of koche products and thereby increase incomes of pastoral communities.
\end{abstract}

Keywords: Indigenous meat products, Commercial viability, Processing, Profitability

\section{Introduction}

Pastoralism is an economic activity that is based on animal production. It is largely practised in the arid and semi-arid lands (ASALs) of Kenya and has shaped livelihoods for millennia. Livestock, labour and access to grazing areas and water resources are key requirements for pastoralist production (Homewood et al. 2012). In Kenya, pastoralism is a way of life for about six million people living in the ASALs. The pastoral communities include the Somali, Maasai, Borana, Rendille, Gabra and Turkana with an estimated livestock worth of US\$800 million per year (Lindqvist and Verba 2009). Pastoral systems contribute significantly to the economy. About

\footnotetext{
* Correspondence: graceethel@yahoo.com

'University of Nairobi, P. O BOX 29053-00625, Kangemi, Nairobi, Kenya Full list of author information is available at the end of the article
}

$70 \%$ of beef cattle in Kenya are from the ASALs under pastoral production systems (EPZA 2005).

Over time, pastoralists have relied on indigenous knowledge to add value to beef and beef products. Local preservation techniques such as drying, salting, using spices and deep-frying were employed for the sole purpose of increasing shelf life, preventing spoilage and enhancing flavour and taste (Rai and Palni 2009; Bora and Bam 2014; Gichure et al. 2014). As a result, a variety of indigenous meat products have been developed including enyas, olpurda, nyirinyiri and koche. The indigenous meat products are region-specific and have unique substrates and preparations. Preparations depend on culture, climate, process and availability of materials (Gichure et al. 2014).

Koche is a dried traditional meat product which undergoes various stages of processing. It is made from beef, 
camel or goat muscle, particularly from the sirloin or the silverside steak. It is a dehydrated food product as moisture is reduced in different ways during processing. As a way of preservation, women among the Borana community cut meat into thin strips to dry under the sun for 2 or 3 days. Additionally, they deep-fry the meat to evaporate more moisture (Dabasso et al. 2018).

In the context of human nutrition, food processing is important. Food processing adds variety and convenience in order to meet various lifestyle requirements. It also plays an important role in the national economic development (Sharma and Kondaiah 2005). However, current research has shown that indigenous meat processing by the pastoral communities faces a number of constraints, which hinders further development. Though many of the traditional meat products have great potential, they are made only for local consumption with little in the way of commercialization (Gichure et al. 2014). This study was hence conducted with the ultimate aim of assessing the status of processing of koche product to highlight challenges and opportunities for the industry's development and prosperity.

\section{Materials and methods}

\section{Study area}

The study was conducted in Marsabit and Isiolo counties. The two counties were purposively selected since the majority of the residents are of pastoral origin and depend largely on meat and milk products for their basic food needs (Homewood et al. 2012). Marsabit County has a population of about 291,166 people. The area receives an annual rainfall range of 200 to $1000 \mathrm{~mm}$. The area receives an annual rainfall of $418 \mathrm{~mm}$ (Mati et al., 2005). Temperature ranges from a minimum of $10^{\circ} \mathrm{C}$ to a maximum of $30^{\circ} \mathrm{C}$ with an average of $20^{\circ} \mathrm{C}$ (KNBS (Kenya National Bureau of Statistics) 2009). Isiolo County has a population of about 143,294 people (KNBS (Kenya National Bureau of Statistics) 2009). The area is typically semi-arid. The rainfall pattern is bimodal and erratic in distribution. Average annual temperatures range from 24 to $30^{\circ} \mathrm{C}$ (Herlocker et al. 1993). Figure 1 shows the counties and towns visited.

\section{Study design}

The design was cross-sectional consisting of a survey in the two counties.

\section{Sampling and data collection}

A total of ten processors were purposively identified as study cohorts. The selection of the processors was according to their knowledge on indigenous meat processing and those involved in commercial processing. Focus group discussions were conducted with processors to assess the current status of processing koche products.
The focus group discussions had eight to ten participants. A checklist guide was used to guide the data collection. The questions focused on traditional processing and preservation, challenges and benefits.

To triangulate data received from FGDs, key informant interviews (KIIs) were conducted with the processors. Unstructured interview guides were used to guide the data collection. The questions in the guide were focused on socio-economic characteristics of koche processors, traditional processing and preservation, inputs used in koche processing, quantities used, unit prices, production output, challenges and opportunities. Observations of processing and hygiene were also done and recorded in the field notebook.

\section{Data analysis}

Qualitative data collected through FGDs and KIIs were entered into the Nvivo application, grouped and analysed to bring about the proportions and narratives. Observations were also recorded in the application and summarized in paragraphs. Inferential statistics such as gross margin analysis and marketing margin analysis were used. Descriptive statistics such as percentages was used to represent the input variables used and returns obtained.

\section{Gross margin model}

Gross margin analysis was used to determine the profitability of koche processing in the study area. It was expressed as follows:

$$
\mathrm{GM}=\mathrm{GR}-\mathrm{TVC}
$$

where:

$\mathrm{GM}=$ Gross margin (Kshs)

$\mathrm{GR}=$ Gross revenue (Kshs)

TVC $=$ Total variable costs (Kshs) (Iliyasu et al. 2013)

Gross margin was used because the fixed costs of processing of koche product are negligible (Iheanacho and Philip 2002).

\section{Marketing margin analysis}

Percentage marketing margin is the difference between the sales revenue and the cost price divided by the cost price and multiplied by 100 (Iliyasu et al. 2013).

The formula is expressed as follows:

$$
\mathrm{MM}=\frac{\mathrm{CPP}-\mathrm{PRP}}{\mathrm{CPP}} \times 100
$$

where:

$\mathrm{MM}=$ Marketing margin

$\mathrm{CPP}=$ Consumer's paid price

PRP $=$ Producer's received price (Iliyasu et al. 2013) 


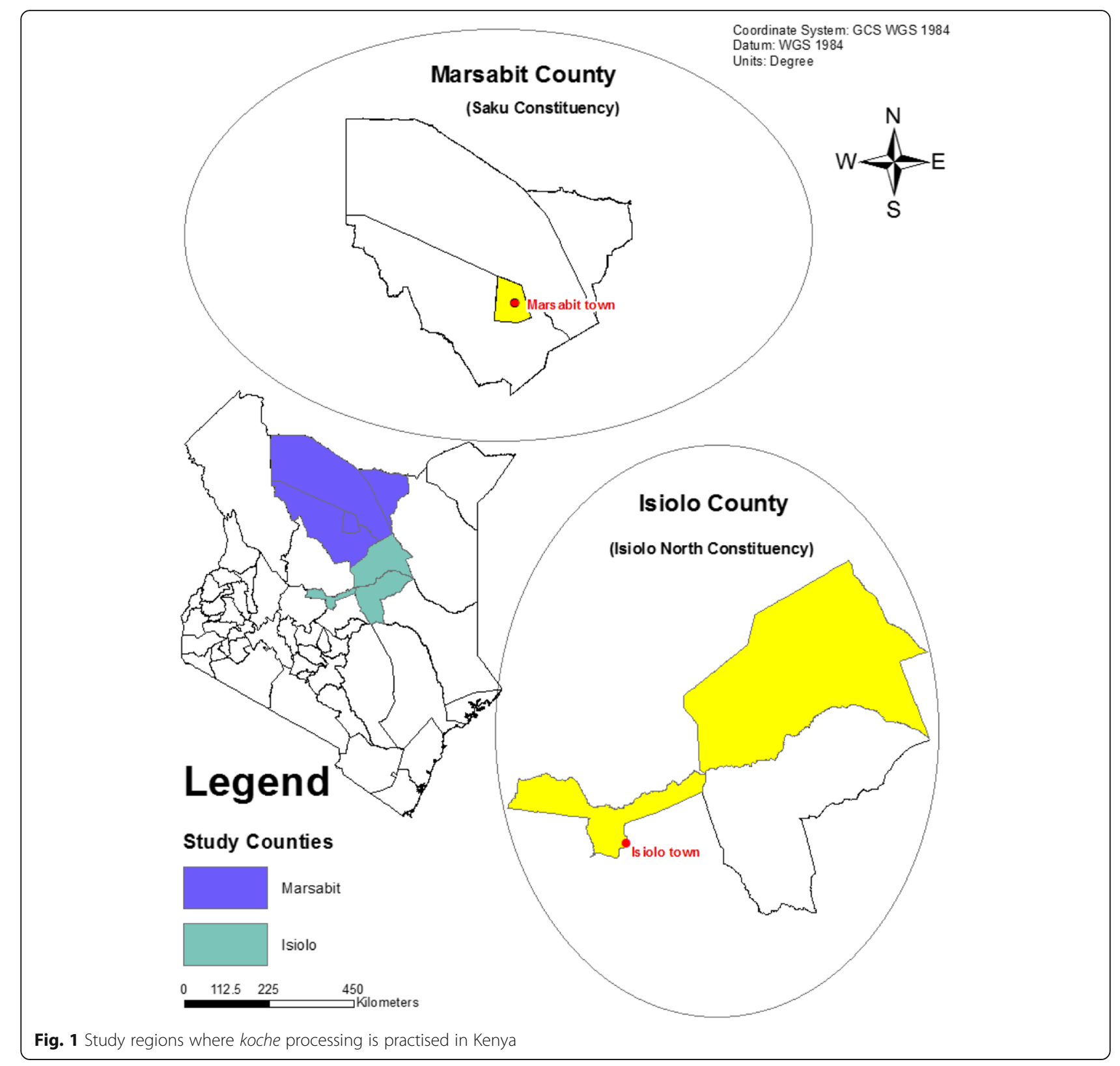

\section{Results}

\section{Socio-demographic characteristics of the processors}

Ten major commercial processors were identified in the study area. All the processors were women. The majority of them (70\%) had an age range of 46 years and above. Processing of koche product was their main source of income. Among the processors, $50 \%$ had a processing experience of 4-9 years. In addition, most of them (80\%) were illiterate and only a few (20\%) had achieved the primary level education (Table 1). However, this did not deter them from participating in the processing activities, which were done individually. The study results also show that the main source of finance for the business was personal savings. The processors did not belong to any co-operatives or associations.

\section{Processing of koche product}

The study shows that processing of koche product was largely carried out in individual households. The process analysis shows that koche was prepared using multiple steps as highlighted in Figs. 2 and 3. The amount of koche product processed depended on the orders received from traders. The average quantity processed per day was $50 \mathrm{~kg}$. The raw material used was camel or beef meat sourced from butchery establishments. Salting was a technique used with ingredients such as sodium chloride (0.25\%). 
Table 1 Socio-demographic characteristics of koche processors

\begin{tabular}{ll}
\hline Variables & Percentage \\
\hline Age & 0 \\
$26-35$ years & 30 \\
$36-45$ years & 70 \\
46 and above years & \\
Production experience & 50 \\
$4-9$ years & 30 \\
10-15 years & 20 \\
16-21 years & 0 \\
More than 21 years & \\
Education level & 80 \\
No education & 20 \\
Primary level & 0 \\
Secondary level &
\end{tabular}

Salting was done prior to drying. Salting is a method of preservation that acts by reducing the water activity so there is less water available for microbial growth, thus increasing the shelf life. Drying allows the migration of water from the product to the external environment, leading to a decrease in water activity and distribution of salts and other compounds in the product. Deep-frying was done at $100{ }^{\circ} \mathrm{C}$ oil temperature for $30 \mathrm{~min}$ to further reduce the water activity. Addition of spice such as cardamom $(0.045 \%)$ was done during deep frying to impart flavour. After deep-frying, the product was finally cooled and the quality evaluated based on taste and colour only.

However, processors did not observe good manufacturing practices; often, there was no running water at the processing sites and personnel involved in processing did not wear appropriate protective clothing. Additionally, during the drying of the product, chances of contamination from flies and dust were very high.

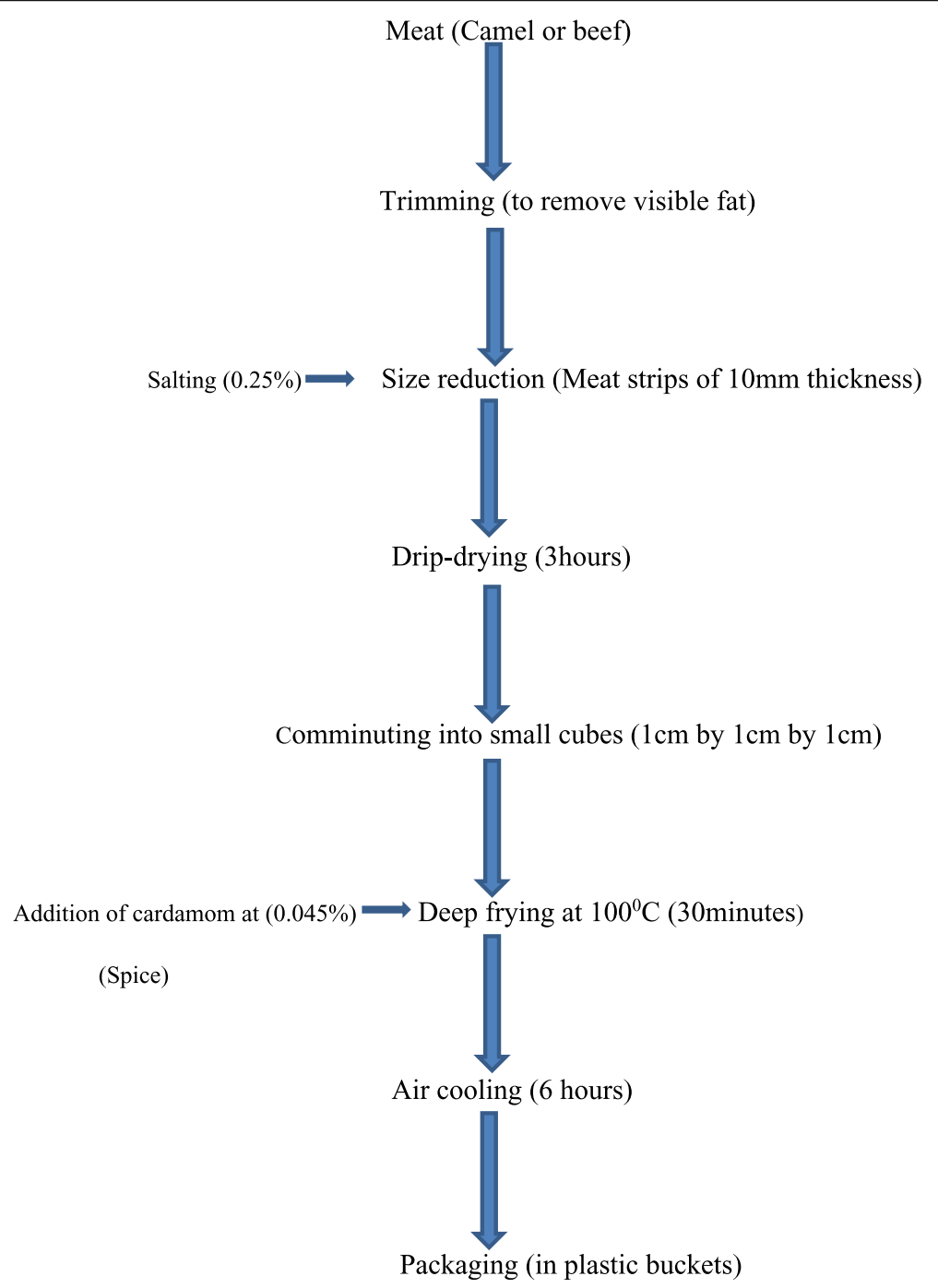

Fig. 2 Process analysis of koche, a traditional pastoral meat snack 


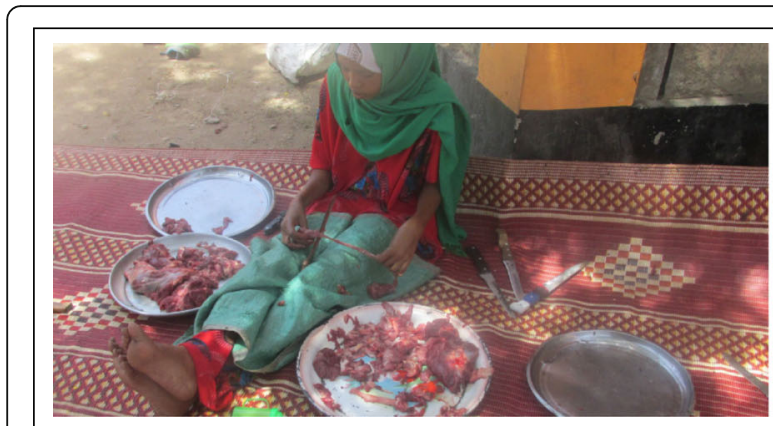

A

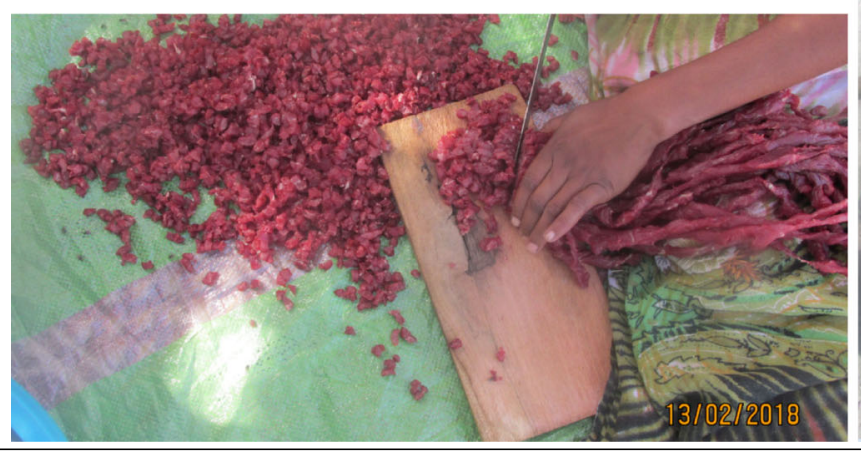

C

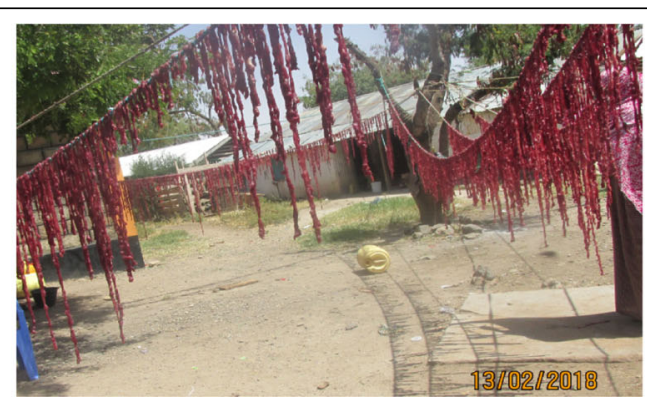

B

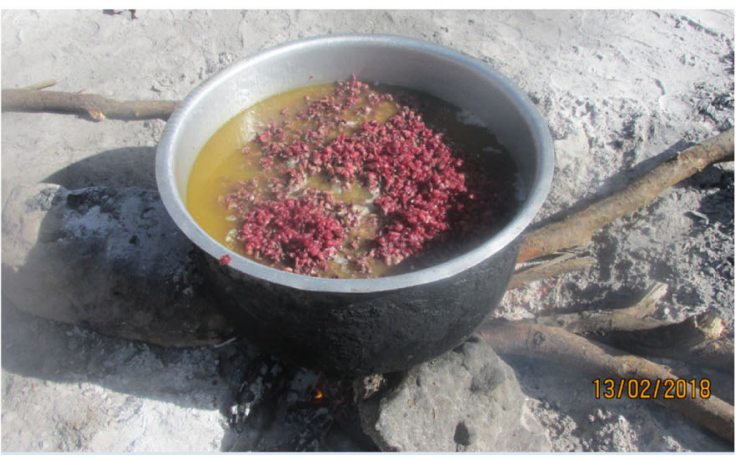

D

Fig. 3 Pictorial representation of traditional processing of koche product. a Size reduction (cutting meat strips). b Drip-drying of meat strips. c Size reduction (cutting of meat strips into cubes). $\mathbf{d}$ Deep-frying of meat cubes

\section{Labour division for processing koche product}

Depending on the amount of koche product processed, processors employed workers on a daily basis to assist in processing. The daily wage paid was $400-500 \mathrm{Kshs}$ (4-5 USD) per labourer. Table 2 shows the labour division for processing $50 \mathrm{~kg}$ of koche product. The majority (71\%) of the employed personnel were involved in the cutting process. According to the processors interviewed, cutting of meat into strips is a tedious process, thus requiring a lot of personnel (Fig. 3a).

\section{Costs and returns of koche processing}

The results presented in Table 3 show that the costs of the major variable inputs used in koche processing included the cost of meat (71.7\%), ingredients $(0.354 \%)$,

Table 2 Labour division and time required for processing $50 \mathrm{~kg}$ of koche product

\begin{tabular}{llll}
\hline Activities & $\begin{array}{l}\text { Number of personnel } \\
\text { required }\end{array}$ & $\begin{array}{l}\text { Percentage of } \\
\text { personnel }\end{array}$ & Time spent/day \\
\hline Cutting & 5 & 71 & $4 \mathrm{~h}$ \\
Drying & 1 & 14 & $5 \mathrm{~h}$ \\
Frying & 1 & 14 & $2 \mathrm{~h}$ \\
\hline
\end{tabular}

cooking oil (13.34\%), transport (1.77\%), firewood (2.66\%), labour $(7.56 \%)$ and packaging material (0.03\%). The cost of meat constituted the highest cost of processing. The findings also show that for $20 \mathrm{~kg}$ of meat processed, $18 \mathrm{~kg}$ of koche product was produced and the total revenue of $18 \mathrm{~kg}$ of koche product was Kshs 21,600 (216 USD).

The total gross margin was Kshs 10,360 (103.6 USD). Analysis of the returns shows that for every shilling invested on variable inputs in producing koche product, a gross margin of Kshs 0.92 (0.0092 USD) was realized, while the return to labour was Kshs 12.1 (0.121 USD). The study revealed that the producers' received price for koche product was Kshs 950 (9.5 USD), while the consumers' paid price for koche product was Kshs 1200 (12 USD). Thus, the marketing margin for koche product was estimated as $20.8 \%$.

\section{Challenges faced by koche processors}

The problems facing koche processors in the study area are presented by multiple responses in Table 4 . Challenges were related to capital, transport, equipment, market, payment, inputs and credit facilities. The major constraints identified were lack of equipment to ease processing $(100 \%)$, lack of credit facilities (100\%), insufficient capital (90\%) and high costs of inputs (90\%). 
Table 3 Average costs and returns of processing $20 \mathrm{~kg}$ of camel meat into koche product

\begin{tabular}{|c|c|c|c|c|c|}
\hline Category & $\begin{array}{l}\text { Quantity } \\
\text { (Kg) }\end{array}$ & $\begin{array}{l}\text { Unit price } \\
\text { (per kg) }\end{array}$ & $\begin{array}{l}\text { Value } \\
\text { (Kshs) }\end{array}$ & $\begin{array}{l}\text { Value } \\
\text { (USD) }\end{array}$ & $\begin{array}{l}\text { Percentage (\%) } \\
\text { of the total cost }\end{array}$ \\
\hline Returns & 18 & 1200 & 21600 & 216 & \\
\hline \multicolumn{6}{|l|}{ Koche produced } \\
\hline \multicolumn{6}{|l|}{ Variable costs } \\
\hline Meat & 20 & 400 & 8000 & 80 & 71.17 \\
\hline \multicolumn{6}{|l|}{ Ingredients } \\
\hline Salt & 0.05 & & 10 & 0.1 & 0.088 \\
\hline $\begin{array}{l}\text { Cardamom } \\
\text { (spice) }\end{array}$ & 0.09 & & 30 & 0.3 & 0.266 \\
\hline Cooking oil & 10 & & 1500 & 15 & 13.34 \\
\hline Transport & & & 200 & 2 & 1.77 \\
\hline Firewood & & & 300 & 3 & 2.66 \\
\hline Labour & & & 850 & 8.5 & 7.56 \\
\hline $\begin{array}{l}\text { Packaging } \\
\text { material }\end{array}$ & & & 350 & 3.5 & 0.03 \\
\hline $\begin{array}{l}\text { Total Variable } \\
\text { costs }\end{array}$ & & & 11240 & 112.4 & 100 \\
\hline Gross Margin & & & 10360 & 103.6 & \\
\hline $\begin{array}{l}\text { Marketing } \\
\text { margin \% }\end{array}$ & & & & & 20.8 \\
\hline $\begin{array}{l}\text { Return to } \\
\text { variable costs }\end{array}$ & & & 0.92 & 0.0092 & \\
\hline $\begin{array}{l}\text { Return to } \\
\text { labour }\end{array}$ & & & 12.1 & 0.121 & \\
\hline
\end{tabular}

\section{Discussion}

The present study provides evidence that processing of koche product is a source of livelihood for the women processors. The socio-economic characteristics of the processors clearly showed that processing was mostly done by older women with the majority lacking formal education. Similar observations were made by Madete et al. in Nigeria (2015) who found out that most actors involved in indigenous meat product (nyirinyiri) processing had an age bracket of 40-60 years with no formal

Table 4 Challenges faced by koche processors

\begin{tabular}{lll}
\hline Challenges & $\begin{array}{l}\text { Number of processors } \\
\text { reporting the problem }\end{array}$ & Percentage \\
\hline Insufficient capital & 9 & 90 \\
Poor transport system & 5 & 50 \\
Poor market access & 7 & 70 \\
$\begin{array}{l}\text { Delayed payment } \\
\text { upon supply. }\end{array}$ & 6 & 60 \\
Lack of equipment & 10 & 100 \\
to ease processing & & 100 \\
Lack of credit facilities & 10 & 90 \\
High cost of inputs & 9 & \\
\hline
\end{tabular}

education. The survey of processing techniques employed showed that processors used simple indigenous knowledge in processing of koche products. This reflects not only the women's skills and creativity but also their capability to sustain the dynamics of life and ecosystem. In fact, Asogwa and Okoye (2017) noted that women in Africa have used indigenous knowledge in processing of food, thus generating income and employment opportunities. However, the existing level of processing hygiene was poor. This corroborates the results of Kardivel et al. (2018) who reported similar observations in India in regard to hygiene and quality practices of traditional processors.

In addition, several authors (Kisembe et al. 2017; Gichure et al. 2014) in Kenya have identified poor hygiene of indigenous meat products as a major concern. Therefore, the subjective assessment of safety and quality of the final product based on taste and colour was inadequate in addressing the hygiene issues observed in processing and unlikely to meet the quality and safety requirements of consumers.

According to Hudson and Hite (2003), sociodemographic factors such as educational level, age and poverty are important predictors in the understanding of food quality and safety. Therefore, the low levels of education of the processors influenced the lack of adoption of food quality and safety standards. Nevertheless, Khan (2005) reported that effective communication strategies and access to institutional services and input supply markets can facilitate the adoption of food safety and quality standards by processors, thus improving hygiene.

The findings on gross margin analysis indicate that koche processing is a profitable business mainly influenced by the cost of meat, as in Nigeria (Ahmadu et al. 2004 and Ahmadu et al. 2008a; Iliyasu et al. 2013). According to the findings, the processors strongly agreed that lack of credit facilities was a major challenge which consequently had an adverse effect on the capital. As a result, the processors were constrained in expanding production. The high costs of inputs were attributed to the high cost of meat. Poor market access was highly attributed to insufficient product and market promotion. These findings therefore concur with other studies in Nigeria that reported similar challenges in small-scale meat production enterprises (Ahmadu et al. 2004; Ahmadu et al. 2008b).

\section{Conclusion}

Based on the results presented, koche processing is still in extremely infant stages despite the potential. Being labour intensive, it can be a tool for poverty eradication and economic empowerment for women and youth as ascribed in Kenya Vision 2030. 


\section{Recommendation}

To counter the highlighted challenges, the following measures should be adopted:

- Processors should progressively be trained and equipped with good quality control measures during processing.

- Government should set clear policies that aim at improving livestock production.

- Government and financial institutions should provide affordable and easy-to-access financial mechanisms to processors.

- Processors need to be empowered to practise value addition in order to gain a competitive edge for their products in the market.

\section{Acknowledgements}

The authors acknowledge and thank the RELOAD project funded by the German Federal Ministry of Education and Research through the University of Kassel for funding the study.

\section{Funding}

This research was funded by the German Federal Ministry of Education and Research.

\section{Availability of data and materials}

Please contact author for data requests.

\section{Authors' contributions}

GW, the main author, was involved in recruiting the enumerators and data collection, analysis and interpretation. She also drafted the manuscript and submitted it. CNK made substantial intellectual inputs from conception and during research process and manuscript writing. MWO made substantial intellectual inputs from conception and during research process and manuscript writing. HGR made substantial intellectual inputs from conception and during research process and manuscript writing. All the authors read and approved the final manuscript to be published.

\section{Ethics approval and consent to participate}

Not applicable in this study.

\section{Consent for publication}

As per international standard or university standard, a written consent form has been collected and preserved by the authors.

\section{Competing interests}

The authors declare that they have no competing interests.

\section{Publisher's Note}

Springer Nature remains neutral with regard to jurisdictional claims in published maps and institutional affiliations.

\section{Author details}

${ }^{1}$ University of Nairobi, P. O BOX 29053-00625, Kangemi, Nairobi, Kenya.

${ }^{2}$ National Museums of Kenya, Nairobi, Kenya.

Received: 7 September 2018 Accepted: 11 February 2019

Published online: 25 March 2019

\section{References}

Ahmadu, J., G.O. Alufohai, P.O. Erhabor, and J.O. Igene. 2008a. Profitability of Kilishi production under traditional and modern technologies in Nigeria. Journal of Sustainable Tropical Agricultural Research 28: 14-21.

Ahmadu, J., P.O. Erhabor, S.I. Orewa, and J.O. Igene. 2008b. Resource use efficiency in traditional Kilishi production in Bauchi and Kaduna States of Nigeria. Journal of Agricultural Research and Policies 3 (2): 51-64.
Ahmadu, J., J.O. Igene, C.I. Ada-Okungbowa, and H.A. Agboola. 2004. Economics of kilishi production in Nigeria. Applied Tropical Agriculture: An International Journal 9: 25-33.

Asogwa, I.S., and J.I. Okoye. 2017. Promotion of indigenous food preservation and processing knowledge and the challenge of food security in Africa. Journal of Food Security 3: 75-87 Elsevier.

Bora, L., and J. Bam. 2014. Traditional milk, meat processing and preservation techniques of the yak pastoralists of Arunachal Pradesh. Indian Journal of Traditional Knowledge 131 (1): 216-221

Dabasso, B.G., H.G. Roba, A. Makokha, A. Onyango, and J. Maina. 2018. Understanding traditional meat processing knowledge among the Borana pastoralist of Northern Kenya. Journal of Food Research 7: 4 Elsevier.

EPZA (2005) Meat production in Kenya 2005, Export Processing Zones Authority.

Gichure, J.N., C.N. Kunyanga, P.M. Mathi, and J.K. Imungi. 2014. Present status of meat processing and preservation in the pastoral regions of Kenya. Food Science and Quality Management 34: 42-50 Google Scholar.

Government of Republic of Kenya. 2007. Kenya Vision 2030. Ministry of Devolution and planning. Nairobi; Government printer.

Herlocker, D.J., S.B. Shaaban, S.Wilkes.(1993) Range management handbook of Kenya. Volume II, 5: Isiolo District. Nairobi: Ministry of Agriculture, Livestock Development and Marketing.

Homewood, K.M., P.C. Trench, and D. Brockington. 2012. Pastoralist livelihoods and wildlife revenues in East Africa: A case for coexistence? Pastoralism, Policy and Research Journal 2: 19.

Hudson, D., and D. Hite. 2003. Willingness to pay for water quality improvements: The case of precision application technology. Journal of Agricultural Resource Economics 27: 433-449 Google Scholar.

Iheanacho, A.C., and D.O.A. Philips. 2002. Costs and Returns of Millet-Based Crop Mixtures in the Arid zone of Nigeria. A case study of Borno state, Nigeria. Journal of Arid Agricutural, 12: 131-135.

Iliyasu, A., A.C. Iheanacho, and S.I. Mshelia. 2013. Profitability analysis of three methods of suya production and marketing in Maiduguri Metropolitan Council, Borno State, Nigeria. Nigerian Journal of Basic and Applied Sciences 16 (2): 257-262. Available online at https://www.ajol.info.

Kardivel, G., B.B. Banerjee, S. Meitei, S. Doley, A. Sen, and M. Muthukumar. 2018. Market potential and opportunities for commercialization of traditional meat products in north east hill region of India. Veterinary World 11 (2): 118-124.

Khan, S.A. 2005. Introduction to extension education. In Extension Methods, ed. R. A. Memon and E. Bashir, 3rd ed. Islamabad: National Book Found.

Kisembe, S.W., P.S. Muliro, J.W. Matofari, and B.O. Bebe. 2017. An evaluation of nutritional quality of traditionally processed camel meat (Nyirinyiri): Value chain assessment and recommendations. International Journal of Nutrition and Food Sciences 6 (4): 172-174.

KNBS (Kenya National Bureau of Statistics). 2009. Population and housing census. Kenya National Bureau of Statistics 2010 Available at http://www.knbs.or.ke. Accessed 19 June 2017

Lindqvist, A.K., and T. Verba. 2009. Overview of drylands development communication initiatives in Africa. Chicago. http://pubs.iied.org/pdfs/G02494.pdf

Madete, S.K. Pauline, Bockline O. Bebe, Joseph W. Matofari, Patrick S. Muliro, and Edwin B. Mangeni. 2015. Communicating food quality and safety in the informal market outlets of pastoral suusa and nyirinyiri products in Kenya. Agriculture, Forestry and Fisheries 4: 216-221 Elsevier.

Mati, B.M., J.M. Muchiri, K. Njenga, F. Penning de Vries, and D.J. Merrey. 2005. Assessing water availability under pastoral livestock sytems in drought prone Isiolo District, Kenya. Working paper 106. Colombo, Sri-lanka international water management instittue ( IWM)

Rai, A., and U. Palni. 2009. Traditional knowledge of the Himalayan people on production of indigenous meat products. Indian Journal of Traditional Knowledge 08 (1): 104-109.

Sharma, B.D., and N. Kondaiah. 2005. Development of Buffalo meat samosa and evaluation of its storage in low vacuum family park under frozen condition. Journal of Veterinary Public Health 2 (3): 59-62. 